\title{
Financial Ratio Analysis that could Predict Financial Distress on Islamic Bank
}

\author{
Intan P.S. Hasibuan ${ }^{1}$, Nurhasanah ${ }^{2}$, Mahroji $^{3}$, Mas Rangga Cili ${ }^{4}$ \\ \{Intanabigailzrh@yahoo.com ${ }^{1}$, nurhasanah@mercubuana.ac.id ${ }^{2}$, mahrojifarras@yahoo.com ${ }^{3}$, \\ anggacili@gmail.com $\left.{ }^{4}\right\}$ \\ Universitas Mercu Buana, Indonesia ${ }^{1}$, Universitas Mercu Buana, Indonesia ${ }^{2}$, Universitas Mercu \\ Buana, Indonesia ${ }^{3}$, Politeknik APP Jakarta ${ }^{4}$
}

\begin{abstract}
The purpose of this study was to determine the influence of Capital Adequacy Ratio, Financing to Deposite Ratio and Non-Performing Financing on Financial Distress. The object of research is 11 Islamic Commercial Banks registered in the Financial Services Authority (OJK) and Bank Indonesia (BI), with data from 2013 to 2017. The research was conducted with quantitative methods, to test the influence of independent variables on the dependent variable. Analysis of the data used is descriptive statistical analysis and hypothesis testing in the form of multiple linear regression tests, and assisted by SPSS software. The results of this study indicate that the Capital Adequacy Ratio, and Financing to Deposite Ratio each have no significant influence on financial distress, while Non-Performing Financing has a significant positive influence on Financial Distress.
\end{abstract}

Keywords: Capital Adequacy Ratio, Financing to Deposite Ratio, Non-Performing Financing, Financial Distress.

\section{Pendahuluan}

Bank syariah (bank umum syariah) dan bank konvensional (bank umum) dalam beberapa hal memiliki kesamaan, namun ada beberapa hal mendasar yang membedakan keduanya. Apabila dilihat dari sisi fungsi sebagai lembaga perbankan, bank umum syariah dan bank umum melaksanakan fungsi yang sama yaitu dengan melakukan penghimpunan dan penyaluran dana, disamping memberikan pelayanan atas jasa perbankan lainnya. Perbedaan utamanya adalah dalam menjalankan setiap aktivitas bisnisnya bank umum syariah senantiasa mengedepankan prinsip prinsip syariah (1). Penilaian Tingkat Kesehatan Bank umum wajib dilakukan sendiri, hal ini tertuang Surat Edaran Bank Indonesia tanggal 25 Oktober 2011, yang membahas mengenai kewajiban bank untuk melakukan penilaian tingkat kesehatan bank, adapun alat ukur yang di gunakan pendekatan Risiko (Risk-based Bank Rating/RBBR). Penilaian risiko meliputi profil risiko, good corporate governance, rentabilitas dan permodalan bank. Hal tersebut berbeda dengan yang berlaku pada bank syariah. Tahun 2014, penilaian tingkat kesehatan bank umum syariah dan unit usaha syariah, di keluarkan oleh Otoritas Jasa Keuangan (OJK) dalam bentuk Surat Edaran Nomor 10/SEOJK.03/2014, sebagai tindak lanjut dari POJK Nomor 8/POJK.03/2014, dikenal tambahan 2 jenis risiko yaitu Risiko Imbal Hasil (rate of return risk) dan Risiko Investasi (equity investment risk). Risiko 
perbankan berbeda dengan risiko pasar modal, sehingga pengukuran risiko atas instrument keuangannya juga berbeda (2).

Perkembangan perbankan syariah di Indonesia hingga tahun 2017 hanya 4\% dari total aset perbankan nasional, meskipun terjadi peningkatan aset perbankan syariah setiap tahunnya. Tabel 1 dibawah ini menunjukkan perbandingan aset bank syariah dan bank konvensional di Indonesia dari tahun 2013 hingga tahun 2017.

Tabel 1. Perbandingan Aset Bank Umum Syariah dan Bank Umum di Indonesia (dalam triliun rupiah)

\begin{tabular}{ccc}
\hline \multirow{2}{*}{ Tahun } & \multicolumn{2}{c}{ Total Aset } \\
\cline { 2 - 3 } & $\begin{array}{c}\text { Bank Umum } \\
\text { Syariah }\end{array}$ & Bank Umum \\
\hline 2013 & 242.276 & 4.954 .467 \\
2014 & 272.343 & 5.410 .189 \\
2015 & 213.422 & 5.915 .724 \\
2016 & 254.182 & 6.475 .618 \\
2017 & 288.025 & 7.099 .609 \\
\hline
\end{tabular}

Sumber: SPI dan SPS Desember 2013, 2016 \& 2018 (website:ojk.go.id)

Capital Adequency Ratio (CAR), Financing to Deposite Ratio (FDR) dan Non Performing Financing $(N P F)$ merupakan beberapa alat indikator keuangan yang dapat digunakan untuk mengukur perkembangan suatu usaha atau bisnis, yakni perbankan syariah Indonesia dalam hal ini. Dalam Tabel 2, rasio CAR mengalami kenaikan sebesar 3,46\% dari 14,45\% di tahun 2013 menjadi 17,91\% padaha tahun 2017, sebaliknya rasio FDR mengalami penurunan sebesar 20,67\% pada periode yang sama. Sedangkan rasio NPF mengalami kenaikan tertinggi padah tahun 2014 yaitu sebesar 4,95\% namun kemudian turun hingga 4,77\% di tahun 2017. Akan tetapi NPF tetap menunjukan kenaikan dari tahun 2013 hingga 2017 sebesar 2,15\%

Tabel 2. Rasio Keuangan CAR, FDR, NPF Bank Umum Syariah

\begin{tabular}{ccccc}
\hline Tahun & CAR & & FDR & NPF \\
\cline { 1 - 2 } 2013 & $14,45 \%$ & & $100,32 \%$ & $2,62 \%$ \\
2014 & $15,74 \%$ & & $86,66 \%$ & $4,95 \%$ \\
2015 & $15,02 \%$ & $88,03 \%$ & $4,84 \%$ \\
2016 & $16,63 \%$ & $85,99 \%$ & $4,42 \%$ \\
2017 & $17,91 \%$ & $79,65 \%$ & $4,77 \%$ \\
\hline
\end{tabular}

Sumber : Otoritas Jasa Keuangan (OJK), 2018

Faktor internal dan eksternal menjadi pemicu kondisi kekurangan likuiditas di kalangan perbankan, persaingan antar bank yang sangat ketat, masalah manajemen perbankan disertai krisis moneter yang terjadi menyulitkan bagi pelaku bisnis keuangan(3). Kesulitan keuangan dalam dunia yang terjadi dalam kurun waktu tertentu dapat menimbulkan financial distress. Financial distress menjadi isyarat awal sebelum terjadinya kebangkrutan, dimana bank 
mengalami kesulitan likuidasi, hutang bank lebih besar dari aset bank. Kondisi ini menyebabkan bank sulit untuk memenuhi kewajibannya. bisa terjadi dalam jangka pendek hingga jangka panjang. Antisipasi terhadap model financial distress harus dilakukan sejak awal, dengan membaca tanda bahwa suatu perusahaan mengalami financial disttres. Diantarannya adalah dengan membaca laporan keuangan pada bank dan menganalisa rasio rasio keungannya, dimana umumnya terjadi penurunan pertumbuhan perusahaan, kemampuan memnghasilkan laba dan juga aset tetap. (4).

Rahmania \& Hermanto (2014) menyatakan Financial distress dipengaruhi secara signifikan oleh NPL, NIM, ROE, dan LD, sedangkan CAR, ROA, dan BOPO tidak . Hasil penelitian Wijaya, Hapsari, \& Kurnia (2018) menunjuukan hasil yang sama. Sedangkan, penelitian Handajani (2012) menunjukkan hal yang berbeda dimana Financial distress dipengaruhi secara signifikan oleh ROA, ROE, dan EPS.

Perbedaan hasil penelitian tersebut, mendasari alasan utama peneliti untuk melakukan penelitian lanjutan untuk mengetahui keterkaitan antar variable terikat dan variable bebas. Penelitian ini merumuskan permasalahan penelitian: apakah CAR, FDR, dan NPF masingmasing berpengaruh terhadap Financial Distress.

\section{Kajian Pustaka, Kerangka Pemikiran, dan Hipotesis}

\subsection{Signalling Theory}

Brigham \& Houston (2012:517) menyatakan sinyal atau isyarat merupakan petunjuk bagi manajemen investor mengenai sebuah tingkat keputusan atau kebijakan yang diambil oleh manajemen perusahaan sehingga dapat menjadi informasi bagi manajemen investor dalam memandang prospek perusahaan. Teori sinyal memberikan informasi kepada manajemen investor mengenai kondisi keuangan, sinyal positif menyiratkan kodisi keuangan yang sedang kondisi keuangan buruk akan memberikan sinyal negatif berdasarkan rasio keuangan. Berdasarkan sinyal tersebut manajeman dapat menetapkan pengambilan keputusan yang tepat sehingga risiko kebangkrutan dapat dihindari sedini mungkin. Teori sinyal merupakan suatu petunjuk mengenai kebijakan atau tindakan yang akan dan telah diambil oleh manajemen perusahaan pada masa lalu, saat ini ataupun masa depan dalam melaksanaan keinginan pemilik perusahaan, sehingga di harapkan penyebaran informasi yang merata antara perusahaan dan pihak luar.

\subsection{Financial distress}

Financial distress adalah kondisi perusahaan yang mengalami kesulitan dana (likuiditas) untuk menutup kewajiban, hutang perusahaan lebih besar dari pada asset perusahaan. Financial distress merupakan tahap ketiga dari terjadinya kebangkrutan perusahaan dengan ditandai kesulitan atau masalah keuangan. Model financial distress harus dikembangkan sejak awal untuk mengantisipasi kapan kebangkrutan akan terjadi. Financial distres mengalami beberapa tahapan yaitu mulai dari tahapan rendah hingga tahapan tinggi dan benar benar membahayakan. (8).

Penyebab terjadinya financial distress ada beberapa diantaranya yaitu kurang pengalaman operasional, manajerial, manajemen yang tidak kompeten, penyelewangan bencana dan lain lainnya, serta keburukan pengelolaan manajemen bank (9). Ditinjau dari 
aspek keuangan, financial distress suatu perusahaan terjadi ketika, perusahaan tidak dapat memenuhi kewajiban-kewajibannya terutama kewajiban jangka pendek, dimana proyeksi arus kas perusahaan tidak sesuai dengan jatuh tempo hutang yang harus dibayarkan, perusahaan mengalami kerugian, dan kinerja perusahan yang terus menerus turun sehingga nilai saham rendah (10).

\subsection{Rerangka Pemikiran dan Hipotesis}

Capital Adequacy Ratio (CAR) merupakan rasio yang di miliki bank untuk melihat apakah modal yang dimiliki cukup untuk menanggung risiko kerugian bank dalam menjalankan bisnisnya, misalnya pembiayaan yang diberikan (11). Capital Adequacy Ratio (CAR) memberikan informasi apakah bank dapat menanggung aktiva tertimbang menurut risiko dengan modal yang di miliki bank. Semakin tinggi rasio CAR, memberikan sinyal positif bagi investor karena mengindikasikan semakin tinggi kekuatan bank dalam menanggung aktiva produktif atau kredit yang berisiko, demikian pula sebaliknya.

Finance to Deposit Ratio (FDR) adalah salah satu rasio keuangan terutama pada bank, yang mengukur kemampuan bank dalam mengembalikan dana deposan yang ditempatkan di bank tersebut. FDR dihitung dari jumlah dana yang disalurkan sebagai pembiayaan dibagi dengan jumlah seluruh penempatan dana oleh deposan sebagai dana pihak ketiga. FDR dapat juga diartikan sebagai efektifitas penyaluran dana oleh bank syariah atas dana deposan yang diamanahkan kepadanya. Pembiayaan kepada nasabah, besarnya di imbangi dengan besarnya dana deposan yang wajib di kembalikan oleh bank, sehingga dana deposan yang digunakan bank untuk pembiayaan dapat di ukur oleh bank. (12).

Rasio Non Performing Financing (NPF) merupakan rsaio yang dimiliki bank untuk melihat apakah bank mampu mengelola pembiayaan yang memiliki potensi masalah. Beberapa tahapan pembiayaan bermasalah pada bank yaitu, kurang lancar, diragukan dan akhirnya macet. Pembiayaan yang bermasalah menyebabkan kesulitan keuangan (financial distress). Pembiayaan dengan risiko tinggi menunjukkan tingkat kesehatan bank yang rendah. Pembiayaan yang bermasalah akan meningkatkan NPF bank. Rahmania \& Hermanto (2014) dalam penelitiannya menyatakan Non Performing Loan (NPL) pada bank menunjukkan hasil signifikan dalam menentukan kesulitan keuangan bank. Angka NPL dapat juga menjadi indikator dari efektifitas mitigasi risiko yang dilakukan oleh manajemen bank syariah, dimana angka NPL yang kecil menunjukkan kinerja yang baik.

Hipotesis dalam penelitian ini adalah sebagai berikut:

H1 : Capital Adequacy Ratio (CAR) berpengaruh terhadap financial distress

$\mathrm{H} 2$ : Finance to Deposit Ratio (FDR) berpengaruh terhadap financial distress

$\mathrm{H} 3$ : Non Performing Finance (NPF) berpengaruh terhadap financial distress

\section{Metode Penelitian}

Berdasarkan sifat penelitian ini yang akan menguji hipotesis, maka penelitian dilakukan dengan pendekatan metode kuantitatif yang berdasarkan filsafat positivisme. Data yang dikumpulkan melalui instrumen penelitian adalah data keuangan perbankan syariah, dan penganalisisan data bersifat statistik guna menguji hipotesis yang telah ditentukan. Pengujian data akan menunjukkan pengaruh variabel-variabel bebas atau variabel yang mempengaruhi, terhadap variabel terikatnya atau variabel yang dipengaruhi. Financial distress sebagai obyek 
penelitian, merupakan variabel terikat (Y) dalam penelitian ini, sedangkan Capital Adequacy Ratio (X1), Financing to Deposite Ratio (X2), dan Non-Performing Financing (X3) sebagai variabel bebas $(\mathrm{X})$ yang dihipotesiskan akan mempengaruhi financial distress.

Populasi pada penelitian ini adalah Bank Umum Syariah yang ada di daftar OJK selama tahun 2013 hingga 2017. Dalam menentukan sampel, digunakan metode Purposive sampling. Dengan purposive sampling didapatkan sampel sebanyak 11 bank umum syariah.

Untuk mengukur financial distress, dalam penelitian ini digunakan metode Altman ZScore yang sudah dimodifikasi dengan lima rasio finansial antara lain Cash flow to total debt, Total debt to total assets, Net income to total assets, Working capital to total assets dan Current ratio. Metode ini digunakan untuk melihat kemungkinan akan terjadinya kebangkrutan di perusahaan, yang dalam penelitian ini adalah perbankan syariah, dengan menggunakan empat komponen yang diformulasikan dengan rumus sebagai berikut:

Keterangan :

$\mathrm{X} 1$ adalah current assets - current liabilities / total assets

$\mathrm{X} 2$ adalah retained earnings / total assets

$\mathrm{X} 3$ adalah earnings before interest and taxes / total assets

$\mathrm{X} 4$ adalah book value of equity / total liabilities

$\mathrm{Z}$ adalah Overall Index

Apabila diperoleh hasil 1,23 $<\mathrm{Z}<2,9$ artinya bahwa bank tersebut masuk dalam wilayah $a b u-a b u$ (tidak dapat dipastikan apakah bank tersebut sehat atau potensial mengalami kebangkrutan). Jika hasil nya $\mathrm{Z}>2,9$ artinya bahwa bank tersebut dalam kondisi sehat. Apabila $Z<1,23$ dapat diartikan bahwa bank dalam kondisi potensial bangkrut. Cukup penting untuk melakukan pengujian Altman Z-Score, agar dapat menghindari kondisi financial distress yang sangat berpotensi pada kebangkrutan bank.

Data dalam penelitian ini berbentuk data keuangan yang merupakan data sekunder yaitu dari laporan keuangan tahunan bank umum syariah, dengan rentang waktu pengamatan dari tahun 2013 hingga 2017.

Analisis data menggunakan metode statistika deskriptif kuantitatif. Metode ini menjelaskan secara deskriptif data pengamatan dari sampel selama tahun pengamatan, namun tujuannya bukan untuk mengambil kesimpulan secara umum. Data juga diuji untuk membuat kesimpulan yang diterima umum terhadap hasil uji data dengan menggunakan uji hipotesis, setelah sebelumnya dilakukan uji asumsi klasik untuk melihat keandalan data.Pengolahan data menggunakan software SPSS.

\section{Hasil dan Pembahasaan}

\subsection{Uji Statistik Deskriptif}


Data yang diamati pada periode 2013 hingga 2017, oleh karena itu jumlah data secara keseluruhan adalah 55 sampel dari Bank Umum Syariah. Hasil pengolahan data dengan menggunakan SPSS 20 adalah sebagai berikut :

1. Nilai minimun CAR adalah 0,1110 atau $11,10 \%$, yaitu pada PT. Bank Syariah Mandiri tahun 2013. Di tahun itu CAR PT. Bank Syariah Mandiri mengalami pertumbuhan lebih rendah untuk modal dari luar perusahaan (jangka panjang) dibandingkan dengan modal sendiri. Nilai maksimum CAR sebesar 0,7583 yaitu pada PT. Maybank Syariah tahun 2017, karena modal jangka panjang mengalami kenaikan dibandingkan dengan tahun sesudahnya yang merosot, sebab proporsi antara jangka panjang dan ekuitas dalam pendanaan investasi meningkat. Nilai mean sebesar 0,214540 menunjukkan bahwa CAR memiliki distribusi yang baik.

2. Nilai minimum Financing to Deposite Ratio (FDR) yaitu 0,7187atau $71,87 \%$ yaitu angka FDR PT. Bank BRI Syariah tahun 2017, sedangkan nilai maksimumnya sebesar 1,5777 atau $157,77 \%$ merupakan angka FDR PT. Maybank Syariah Indonesia tahun 2014. Nilai mean sebesar 0,932325 lebih besar dibandingkan dengan nilai standar devisi sebesar 0,1524484 menunjukan bahwa data FDR memiliki distribusi yang baik.

3. Nilai maksimum Non Performing Financing (NPF) yaitu 0,4399atau 43,99\% pada PT. Maybank Syariah tahun 2016, sedangkan nilai minimum sebesar 0,0000 atau 0\% yaitu pada PT. Maybank Syariah tahun 2017. Nilai mean NPF 0,055689 lebih kecil daripada nilai standar deviasi sebesar 0,0755484 menunjukan bahwa data NPF tidak terdistribusi dengan baik.

4. Nilai minimum Z Score sebesar 0,6972 yaitu pada PT Bank Panin Syariah di tahun 2016, yang artinya nilai tersebut berada di titik kebangkrutan, atau perusahaan berpotensi mengalami kebangkrutan karena nilai $Z<1,23$. Nilai maksimum 6,6749 yaitu pada PT. Maybank Syariah di tahun 2015 memiliki arti bahwa pada titik tersebut perusahaan tidak mengalami kebangkrutan karena nilai $Z>2,9$. Nilai rata-rata sebesar 2,001662 dengan nilai standart deviasi sebesar 0,8640970 yaitu lebih kecil daripada nilai rata-rata. Artinya data Z Score terdistribusi dengan baik.

\subsection{Uji Asumsi Klasik}

Uji normalitas yang dilakukan memberikan hasil bahwa model regresi memenuhi asumsi normalitas. Pada model regresi ini juga tidak ditemukan multikolonieritas diantara variabel independen. Pada uji autokorelasi, nilai Durbin Watson (DW) menunjukkan tidak terjadi masalah autokorelasi, sehingga model regresi tersebut dapat digunakan. Dan melalui uji glejser dapat dikatakan bahwa model regresi telah memenuhi uji heteroskedastisitas.

\subsection{Uji Kelayakan Model}

Besarnya Adjusted $\mathrm{R}^{2}$ adalah 0,119 atau 11,9\%, dapat dijelaskan bahwa Capital Adequacy Rasio (CAR), Financing to Deposit Ratio (FDR), dan Non Performing Financing (NPF) sebagai variabel independen memiliki pengaruh sebesar $11,9 \%$ terhadap financial distress, sedangkan $88,1 \%$ dijelaskan oleh variabel diluar model. Hasil uji $\mathrm{F}$ diperoleh nilai 
signifikansi lebih kecil dari 0,05 dan nilai $\mathrm{F}$ hitung 3,237 > F tabel 3,18 menunjukkan bahwa model regresi yang sedang diuji fit (cocok), untuk menguji signifikansi secara keseluruhan.

\subsection{Uji Hipotesis}

Tabel 3 menunjukkkan hasil uji hipotesis atas data penelitian. Pada hipotesis pertama, nilai signifikansi sebesar 0,706, dimana lebih besar dari $0,05(0,706>0,05)$. Hal ini berarti bahwa hipotesis pertama tidak dapat diterima atau Capital Adequacy ratio tidak mempengaruhi Financial Distress secara signifikan. Pada hipotesis kedua, nilai signifikansi sebesar 0,505, lebih besar dari 0,05 $(0,505>0,005$ yang artinya bahwa hipotesis kedua juga tidak dapat diterima atau Financing to Deposit Ratio tidak mempengaruhi Financial Distress secara signifikan. Pada hipotesis ketiga, nilai signifikansi sebesar 0,004, lebih kecil dari 0,05 $(0,004<0,05)$ yang artinya bahwa hipotesis ketiga diterima atau variabel Non-Performing Financing mempengaruhi Financial Distress secara positif signifikan.

Tabel 3. Hasil Uji t

\begin{tabular}{lrrrr}
\hline Variabel & \multirow{2}{*}{ Koefisien } & \multicolumn{2}{l}{ Standar } & \\
& Error & Signifikansi \\
\hline Konstanta & 2,230 & 0,747 & 2,986 & 0,004 \\
Fdr & $-0,621$ & 0,925 & $-0,671$ & 0,505 \\
Npf & 4,736 & 1,557 & 3,042 & 0,004 \\
Car & 0,404 & 1,065 & 0,379 & 0,706 \\
\hline
\end{tabular}

\section{Kesimpulan}

Capital Adequacy Ratio tidak mempengaruhi financial distress secara signifikan. CAR merupakan salah satu rasio yang dapat digunakan untuk melihat tingkat kemampuan bank dalam mengatasi turunnya jumlah aktiva akibat terjadinya rugi pada bank yang ditimbulkan oleh aktiva berisiko. Dan kerugian bank yang terus menerus dapat memberikan tekanan terhadap likuditas perusahaan sehingga dapat menuju kepada financial distress. Akan tetapi, dalam penelitian ini CAR tidak terbukti sebagai salah satu faktor penentu kebangkrutan. Hal tersebut dapat dimungkinkan karena secara rata-rata nilai CAR bank syariah yang menjadi sampel penelitian menunjukkan angka yang cukup tinggi.

Financing to Deposit Ratio tidak mempengaruhi financial distress secara signifikan . FDR pada bank syariah adalah salah satu rasio untuk mengukur tingkat likuiditas bank tersebut, yaitu dengan menghitung tingkat pembiayaan yang diberikan bank kepada mitranya dengan dana dari deposannya atau dana pihak ketiga. Pengukuran rasio likuiditas bank sangat penting, karena risiko tidak likuidnya kemampuan bank dalam membayar adalah salah satu risiko utama pada bank termasuk bank syariah. Kesulitan likuiditas dapat menuju kepada financial distress. Akan tetapi dalam penelitian ini FDR tidak mempengaruhi financial distress secara signifikan, atau dapat dikatakan FDR tidak dapat digunakan untuk memprediksi financial 
distress. Apabila melihat data penelitian, rata-rata FDR perbankan syariah dalam sampel penelitian adalah 93,23\%. Angka tersebut cukup baik dan masih di kisaran yang diperbolehkan oleh BI yaitu $85-110 \%$, sehingga kurang mampu untuk melihat kemungkinan financial distress.

Non-Performing Financing mempengaruhi financial distress secara positif dan signifikan. NPF adalah rasio pembiayaan bermasalah di bank dibandingkan dengan total pembiayaan. Bank syariah dalam menyalurkan dana kepada mitranya terbebas dari bunga atau riba, namun tetap dapat terjadi gagalnya suatu pembiayaan dimana mitra tidak dapat mengembalikan dana kepada bank syariah sesuai akad. Besarnya jumlah pembiayaan-pembiayaan yang gagal dapat meningkatkan risiko likuiditas, yang kemudian dapat mengarah kepada financial distress.

\section{References}

1. Murniati, Firsta. Pengaruh DPK, NPF, CAR Dan ROA Terhadap Pembiayaan Mudharabah Dan Musyarakah Pada Bank Syariah Mandiri Periode 2011-2016. J Ekon Bisnis Dharma Andalas. 2018;18(1):19-39.

2. Melzatia S, Doktoralina CM, Mahroji M. Yield Sukuk: Maturity, Rating and Value of Emission. SSRN Electron J. 2019;(June).

3. Firmansyah I. Determinant of Non Performing Loan: the Case of Islamic Bank in Indonesia. Bul Ekon Monet dan Perbank. 2015;17(2):241-58.

4. Handajani S. Pengaruh Kinerja Keuangan Terhadap Financial Distress Pada Perusahaan Perbankan Di Bei Pada Tahun 2008-2011. Pengaruh Kinerja Keuang Terhadap Financ Disress Pada Perusah Perbank Di Bei Pada Tahun 2008-2011. 2012;1-4.

5. Rahmania MF, Hermanto SB. Analisis Rasio Keuangan Terhadap Financial Distress. J Ilmu Ris Akunt. 2014;3(11):1-5.

6. Wijaya RR, Hapsari DW, Kurnia. Pengaruh Rasio CAMEL Terhadap Financial Distress pada Bank Umum Syariah di Indonesia Periode 2011-2015. 2018;5(1):78695.

7. Brigham EF, Houston JF. Fundamentals of Financial Management. Mason, OH: Cengage Learning (2007); 2012. 615 p.

8. Khaliq A, Basheer HMA, Thaker HMT, Harun MY, Nahar N. Identifying Financial Distress Firms : A Case Study of Malaysia's Government Linked Companies ( GLC ). Int J Econ Financ Manag. 2014;3(3):141-50.

9. Rodoni A, Ali H. Manajemen Keuangan Modern. 1st ed. Jakarta: Mitra Wacana Media; 2014. 210 p.

10. Sofiasani G, Gautama BP. Pengaruh CAMEL Terhadap Financial Distress Pada Sektor Perbankan Indonesia Periode 2009-2013. J Bus Manag Enterpreneursh Educ. 2016;1(1):136-46.

11. Zulpahmi Z, Sumardi S, Andika A. Banking Management. J Account Bus Res. 2009;2(4):336.

12. Margaretha F, Setiyaningrum D. Likuiditas Bank terhadap Capital Adequacy Ratio Bank- Bank yang Terdaftar di Bursa Efek Indonesia. J Akunt Dan Keuang. 2011;13(1):47-56. 